\title{
Primocane-fruiting Blackberry Breeding
}

\author{
John R. Clark ${ }^{1,2}$ \\ Department of Horticulture, University of Arkansas, 316 Plant Science, Fayetteville, AR 72701
}

\author{
Additional index words. Rubus, small-fruit breeding, fruit quality, heat tolerance
}

\begin{abstract}
Primocane-fruiting blackberry breeding was initiated in the early 1990s at the University of Arkansas. The source of this trait is the diploid genotype 'Hillquist'. Introductions from this effort are the cultivars Prime-Jim ${ }^{\circledR}$ and Prime-Jan ${ }^{\circledR}$. These genotypes are intended for home-garden use as a result of lack of quality for commercial production. Several traits have been identified that are high priorities in primocane blackberry breeding advancement, including heat tolerance of flowers and fruits, fruit quality, thornlessness, and time of fruit ripening. Progress in addressing these limitations through breeding has been positive and the outlook for further improvement of this type of blackberry is promising.
\end{abstract}

Rubus plants are rather unusual among fruit crops in that they have a perennial root system but have biennial canes. The two cane types are primocanes, or first-year canes, which are usually vegetative, and floricanes, which are the same canes and produce fruit in the next growing season. In red raspberry (Rubus ideaus L.), primocane- and floricanefruiting cultivars have substantial commercial value. In blackberry (Rubus subgenus Rubus Watson), floricane-fruiting has been the basis of all blackberry production and commercial primocane-fruiting cultivars did not exist before the release of 'Prime-Jim, ${ }^{\circledR}$ and 'Prime-Jan' ${ }^{\circledR}$ by the University of Arkansas in 2004 (Clark et al., 2005). However, there is much to be done to improve primocane-fruiting blackberries. In my discussion, I highlight potential value of primocanefruiting blackberries, provide background on the origin of this type of fruiting habit, and comment on breeding challenges that have been identified in their early improvement.

\section{POTENTIAL VALUE OF PRIMOCANE BLACKBERRIES}

Primocane-fruiting has several advantages, including: 1) potential of two crops on the same plant in the same year (floricane followed by primocane); 2) later-season (fall) fruiting that is distinctly later than the floricane crop; 3) the potential to schedule production based on primocane management; 4) reduction in pruning costs by mowing of canes (primocane crop only); 5) avoidance of winter injury; 6) production of fruit in an extended geographic area; and 7) potential avoidance of rosette/double blossom disease [caused by Cercosporella rubi (G. Wint.) Plakidas].

The value of primocane-fruiting depends primarily on the growing environment and fruit marketing. For instance, a key time in which availability of blackberry fruit is limited in the United States is September to November, the period when most of the summer production in the United States is complete but before substantial Mexican imports begin. Primocane-fruiting likely will

\footnotetext{
Received for publication 30 Oct. 2006. Accepted for publication 4 Dec. 2006.

${ }^{1}$ University Professor.

${ }^{2}$ To whom reprint requests should be addressed; email jrclark@uark.edu
}

play a role in filling this market window. Winter injury is a major concern in the midwestern to northern United States and prevents reliable fruiting of blackberries. Because canes of primocane types do not need to overwinter, the opportunity exists to grow blackberries in areas where they are usually winter-killed. In areas with inadequate chilling for floricane-fruiting blackberries, primocane production has potential as the need for chilling is eliminated. This might be particularly valuable in Mexico where chemical manipulations of plants are required on floricane-fruiting cultivars.

\section{THE ORIGIN OF TWO PRIMOCANE-FRUITING TRAIT SOURCES FOR BLACKBERRIES}

Primocane-fruiting in blackberries has been very uncommon. I have had several people contact me with comments about primocane-fruiting plants, and maybe it is more common in the wild than I once believed. However, blackberries often produce latebreaking buds from the base of floricanes, and these can be mistaken for primocanes.

The first recorded occurrence of a primocane-fruiting blackberry that I am aware of was a wild plant found by L.G. Hillquist of Ashland, VA. Mrs. Hillquist provided this genotype to the New York State Agricultural Experiment Station in 1949 (USDA, ARS, National Genetic Resources Program, 2006). There is no taxonomic classification of the species of this plant. There is no evidence that this genotype was ever officially named but likely was assigned the cultivar name Hillquist as a designation in New York. This plant was noted to have a "rudimentary" level of primocane-fruiting in Geneva (USDA, ARS, National Genetic Resources Program, 2006). 'Hillquist' is a diploid (Thompson, 1995). There is no record of breeding with this plant until J.N. Moore obtained it in the mid-1960s while accumulating germplasm for the University of Arkansas breeding program. Fortunately, 'Hillquist' is erect-caned, and this contributed to it being used in crossing in Arkansas. Moore made a cross of 'Brazos' $\times$ 'Hillquist' in 1967, and a selection made from this population in 1970 was designated Ark. 593. It was assumed that 'Hillquist' produced an unreduced male gamete to combine with the female gamete of 'Brazos' (a tetraploid plant as are all University of Arkansas blackberries). Based on its success as a parent, Ark. 593 was determined to be a tetraploid selection. Ark. 593 did not express the primocanefruiting trait but was used in subsequent crossing mainly as a result of its early floricane fruit ripening. In the late 1980s, J. Ballington of North Carolina State University obtained plants of Ark. 593, selfpollinated this selection, and recovered primocane-fruiting offspring. Ballington and Moore (1995) released the germplasm selection NC 194. Ballington and Moore hypothesized that the primocane trait was recessivebased. In the early 1990s, Moore's last graduate student, J. Lopez-Medina, undertook a formal study of the inheritance of this trait. His work proposed that the trait is controlled by a recessive allele at a single locus (LopezMedina et al., 2000).

Another substantial effort was undertaken to move the primocane-fruiting trait into blackberry from red raspberry in the United Kingdom (Lim and Knight, 2000). Their approach was to use colchicine to double the chromosome number of diploid red raspberries yielding tetraploid plants that were then crossed to tetraploid and octoploid blackberries and allohexaploid hybrid berries. They successfully transferred the primocane-fruiting trait from raspberry into hybrid berries and found that the primocane-fruiting character had better expression when at least $50 \%$ of the chromosomes in the hybrid genome were from raspberry. Some of the progeny had very large fruit, which detached like blackberries, and had good flavor, indicating commercial potential. However, most of the progeny did not express the primocane-fruiting trait strongly enough or had quality shortcomings. They recommended that the tetraploid and pentaploid hybrids could serve as parents and that subsequent selection of strong primocanefruiting trait expression plus enhanced fruit quality might provide commercial cultivars. As of 2005, this material has not had further improvement nor have any selections proved to be commercially viable (V. Knight, personal communication).

There are likely other sources of primocane-fruiting in blackberries and these might be used in future breeding. An effort will be needed to determine if these sources have combining ability with each other and if the trait is controlled at the same locus in both sources. 


\section{IDENTIFYING THE FIRST CHALLENGES IN PRIMOCANE-FRUITING BLACKBERRY IMPROVEMENT}

The first primocane-fruiting selections in the University of Arkansas breeding program were made on 27 Sept.1997 in Fayetteville, AR, by J. Lopez-Medina, J.N. Moore, and J.R. Clark. The day the selections were made brought a mix of excitement along with challenge. The excitement was seeing these new plants and the range of expression of the trait and fruit quality among the selections. The challenge was that they appeared to be substantially lacking in fruit size and quality compared with the improved erect, floricane-fruiting types from the Arkansas program. The selections were established at the University's Fruit Substation, Clarksville, and observed there beginning in 1998 with the first substantial floricane and primocane crop in 1999. Five of the 14 appeared superior to the others, and these were placed in replicated trials in 2000. Plants of APF-8 and APF-12 (later to be named 'Prime-Jan' ${ }^{\circledR}$ and 'Prime$\mathrm{Jim}^{\text {' }}{ }^{\circledR}$, respectively) were sent to Aurora, OR, for trial by C. Finn, U.S. Department of Agriculture-Agricultural Research Service (USDA-ARS) at the Oregon State University North Willamette Research and Extension Center (OSU-NWREC). Crossing of these new types was begun in Arkansas in 1999.

The seedlings of early crosses were planted on nonirrigated land (most blackberry seedlings in the Arkansas program have been grown in this culture), and dry conditions plus hot temperatures in July and August resulted in primocane plants with little or no fruit. It was then that the need to evaluate primocane-fruiting types at floricane fruiting time was identified with the primocane trait expression verified later in the season (or in another year if the selected plant was moved before the manifestation of primocane buds). This continues to be a major evaluation strategy today in Arkansas.

The evaluation of the first primocane selections continued and it was found the floricane crop was superior to that of the primocanes. Much higher yields, larger fruits, better-quality berries, and other superior traits were found on the floricanes of the primocane types compared with the primocane berries. Small fruits, often with poor color from sunburn, sometimes double fruits, and poor flavor were observed particularly in August and September. I felt at that time that we were years away from a useful primocane blackberry.

A hallmark day for me was 14 Oct. 2001 when I viewed APF-8 and APF-12 at OSUNWREC. The plants had primocanes with large berries ( 8 to $10 \mathrm{~g}$, exceeding the 5 - to 6-g berries seen on floricanes and the 3-g berries seen on primocanes in Arkansas), large amounts of ripe fruit, along with many green and red fruits plus many flowers and flower buds. It was obvious that these genotypes grew much better in the cooler Oregon environment than the Arkansas environment.
Subsequent testing in Arkansas and Minnesota (with J. Luby, University of Minnesota) and New York (with C. Weber, Cornell University) provided a broader view of these selections; plants in the more northern locations produced primocane fruit in limited quantities. These findings plus the Oregon performance resulted in the release of 'PrimeJan' ${ }^{\circledR}$ and 'Prime-Jim' ${ }^{\circledR}$ for the homegarden market. Fruit quality, even in optimum conditions, was not thought to be suitable for commercial markets and yield variations were substantial depending on where these were grown. From these early trials and subsequent investigations, several major traits have been identified for improvement.

\section{PRIMOCANE BLACKBERRIES: THE CHALLENGING TRAITS}

Heat tolerance of flowers. The first trait identified for need of improvement in these early selections was heat tolerance of flowers and fruits. In Arkansas, the primocane types begin blooming in late June (about the time of the completion of floricane fruiting), and the first fruit are ripe in early August. This is a time when temperatures can be above $32{ }^{\circ} \mathrm{C}$ most or all days, much higher compared with April and May when floricane bloom occurs. This observation of damage to flowers by heat was confirmed in growth-chamber studies in Ohio (Stanton, 2007). In the more moderate temperatures of Oregon, the flowers and fruits develop more normally, and primocane fruits are larger than those from the floricanes (Clark et al., 2005). One way to approach this dilemma is to make selections in an environment such as Arkansas to see if heat tolerance can be achieved. It appears that progress can be made in this area because some of the newer primocane-fruiting selections perform better in heat compared with those selected in 1997. Another approach is to evaluate seedlings in a more moderate environment compared with that of Arkansas, also underway at several locations in the world.

Time of primocane bloom and fruit development. The major limitation seen when testing 'Prime-Jan' ${ }^{\circledR}$ and 'Prime-Jim' ${ }^{\circledR}$ in New York and Minnesota was the late date of first ripe primocane fruit. Usually this occurred about 1 Sept., and the remaining fruiting season before frost was very short (J. Luby and C. Weber, personal communication). Development of genotypes with earlier ripening date, much like what was done with red raspberry (Slate and Watson, 1964), is needed. Addressing this issue is being done by intermating the earliest primocane-blooming selections in Arkansas and growing seedlings in Arkansas, Minnesota, and New York. It is hoped that blooming and fruit ripening can be moved earlier and that selection in the northern locations will identify promising segregants. Preliminary observations are that intermating early flowering selections will be successful based on seedlings evaluated from early $\times$ early crosses in Arkansas. Like- wise, crossing of later-blooming selections might be of value to push the date of flowering and fruit maturity later should that be desired for crop scheduling or to delay flowering until a more desirable temperature period.

Thornlessness. Of the original 14 primocane-fruiting selections in Arkansas, one was thornless. It had low vigor and very small fruit size but was used in crossing. Now there are a number of thornless, primocane-fruiting selections in the program. In general, the thornless types have had smaller fruit and expressed the primocanefruiting trait less strongly than most thorny selections. From 2004 to 2006 , substantial progress was made in identifying thornless selections and these are being used heavily in crosses with other thornless primocane fruiters or with one-half thornless primocane-fruiting parents.

Fruit quality. 'Prime-Jan' ${ }^{\circledR}$ and 'Prime$\mathrm{Jim}^{{ }^{\circledR}}$ have fruit quality similar to the softerfruited thorny cultivars from Arkansas, and the fruits are usually not considered firm enough for commercial shipping. Also, flavor is not as good as the thornless cultivars from Arkansas. Flavor can vary greatly with time of ripening, and primocane fruits developing in the heat of the summer in Arkansas often have poor flavor. Double and otherwise misshapen fruit have been seen on primocanefruiting selections. These traits are believed to be associated with high heat during flower bud, flower, and fruit development. Fruit quality involves berry sweetness, acidity, bitterness, color, and symmetry of shape along with postharvest handling potential. Fruit quality has been improved on newer primocane-fruiting selections and at least one has been shown in postharvest evaluations to be near that of thornless genotypes (P. PerkinsVeazie, personal communication). Heavy emphasis is being placed on fruit firmness in selection of parents for crossing and seedling evaluations. Transfer of fruit quality from high-quality, floricane-fruiting thornless parents is a primary mechanism to address quality issues, although usually at least two generations of breeding are required to recover primocane-fruiting progeny.

Yield. This trait is always of great importance in plant breeding and is a major area of focus in primocane blackberry breeding. Yield varies substantially with location on primocane-fruiting types with yields as low as $220 \mathrm{~kg} \cdot \mathrm{ha}^{-1}$ at Clarksville, AR, and exceeding $15,000 \mathrm{~kg} \cdot \mathrm{ha}^{-1}$ in Aurora, OR (Clark et al., 2005). 'Prime-Jan' ${ }^{\circledR}$ is usually higher in primocane yield than 'Prime-Jim, ${ }^{\circledR}$. Floricane yields on these cultivars can be substantial also, equal to thornless and thorny floricane-fruiting cultivars (Clark et al., 2005). Therefore, breeding for yield improvement will likely be location-specific, and emphasis on single (primocane only)- versus double-cropping (floricane and primocane crop) may affect evaluation of seedlings. As of now, both crops are evaluated in the Arkansas program, although single-cropping (primocane only) is done in most evaluations of Arkansas selections in Oregon. 
A key issue in increasing yield from primocanes is to increase flowering on primocanes. It has been found by B. Strik in Oregon that tipping increases primocane yields on 'Prime-Jan' ${ }^{\circledR}$ and 'Prime-Jim' ${ }^{\circledR}$ (Strik et al., 2007). This is likely to become a common practice in the production of this new type of blackberry. In primocane blackberry breeding, I have observed variation in the degree of lateral budbreak on primocanes with some selections having profuse budbreak to the base of the primocanes. This trait should be exploited to increase flowers per cane and, therefore, yield. The intensity of primocane flowering varies in breeding selections, and selecting for intense activity should increase yields.

The road to improvement of primocanefruiting blackberries has only just begun. I believe that this new type of plant, along with the improved floricane-fruiting cultivars, has the potential to substantially increase opportunities for blackberries worldwide. This is an exciting time for blackberries!

\section{Literature Cited}

Ballington, J.R. and J.N. Moore. 1995. NC 194 primocane-fruiting thorny erect tetraploid blackberry germplasm. Fruit Var. J. 49:101-102.

Clark, J.R., J.N. Moore, J. Lopez-Medina, P. Perkins-Veazie, and C.E. Finn. 2005. Prime January (APF-8) and Prime-Jim (APF-12) primocane-fruiting blackberries. HortScience 40 : 852-855.

Lim, Y.K. and V.H. Knight. 2000. The successful transfer of primocane fruiting expression from raspberry to Rubus hybrid berry. Euphytica 116:257-263.

Lopez-Medina, J., J.N. Moore, and R.W. McNew. 2000. A proposed model for inheritance of primocane fruiting in tetraploid erect blackberry. J. Amer. Soc. Hort. Sci. 125:217-221.
Slate, G.L. and J. Watson. 1964. Progress in breeding autumn-fruiting red raspberries. Farming Research 30:6-7.

Stanton, M.A., J.C. Scheerens, R.C. Funt, and J.R. Clark. 2007. Floral competence of primocane-fruiting blackberries Prime-Jan ${ }^{\circledR}$ and Prime-Jim ${ }^{\circledR}$ blackberries grown at three temperature regimes. HortScience 42:508 513.

Strik, B., J.R. Clark, G. Buller, and C. Finn. 2008 Management of primocane-fruiting blackberry to maximize yield and extend the fruiting season. Acta Hort. 777:423-428.

Thompson, M.M. 1995. Chromosome numbers of Rubus cultivars at the National Clonal Germplasm Repository. HortScience 30:14531456.

USDA, ARS, National Genetic Resources Program. 2006. Germplasm Resources Information Network (GRIN) [online database]. National Germplasm Resources Laboratory, Beltsville, MD. 30 Oct. 2006. <http://www.ars-grin.gov/cgi-bin/npgs/ acc/display.pl?1448923>. 